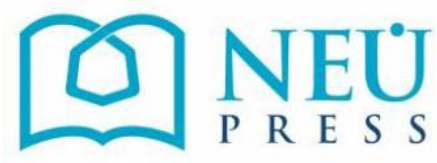

Sayı: 3 Yıl: 2020
Konya Sanat Dergisi

Journal of Konya Art

DOI: $10.51118 /$ konsan.2020.7

\title{
Kubbe-i Hadrâ Kalemişi Tezyînâtı ve Onarımı1
}

\author{
Değerlendiren: Ayşe Zehra SAYIN
}

Öğr. Gör., Necmettin Erbakan Üniversitesi, Güzel Sanatlar Fakültesi, Geleneksel Türk Sanatları Bölümü, Konya,

Türkiye, aysezehra42@gmail.com

\begin{tabular}{lcc}
\hline \multicolumn{3}{c}{ Makale Bilgileri / Article İnfo } \\
\hline \multicolumn{3}{c}{ Makale Geçmişi (Article History) } \\
\hline \multicolumn{1}{c}{ Geliş (Received): 15.10 .2020} & Kabul (Accepted): 11.11 .2020 & Yayın (Published): 25.12 .2020 \\
\hline $\begin{array}{l}\text { Atıf/Citation: Sayın., A, Z. (2020). Kubbe-i Hadrâ Kalemişi Tezyînâtı ve Onarımı, Konya Sanat Dergisi, (3), } \\
\text { 95-97. }\end{array}$
\end{tabular}

Ali Fuat BAYSAL ${ }^{2}$ tarafından kaleme alınan Kubbe-i Hadrâ Kalemişi Tezyînâtı ve Onarımı adlı kitabın ilk baskısı Şubat 2020'de Palet yayınları tarafından yapılmıştır. 2018 yılında başlayan ve yaklaşık bir yıl süren kubbe ve duvar yüzeylerindeki kalemişi onarımı üzerine değerlendirmeler içeren eser, restorasyon çalışmalarının yanı sıra, yapının onarım geçmişine yönelik araştırmaları da kapsaması açısından önem teşkil etmektedir.

Kitap; ön söz hariç Kubbe-i Hadrâ, Kalemişi Tezyînât, Kapsam, Uygulamalar, Kubbe, Kemerler, Güney Duvar Yüzeyi, Kubbe Filayaklarındaki Tezyînât, Restorasyon Çalışmaları, Kubbe-i Hadrâ Kalemişi Tezyînâtını Oluşturan Unsurlar ve Sonuç olmak üzere on ana bölümden oluşmaktadır.

Kubbe-i Hadrâ isimli ilk bölümde Tarihçe alt başlığı altında, Mevlâna için yapılan türbenin inşası ve yaklaşık 745 yıllık zaman diliminde geçirdiği bakım, onarım ve yapılan müdahaleler hakkında bilgi verilmiştir (s. 9). Türbenin dış kısmındaki değişimler hakkında farklı görüşlerin olduğunu ancak iç mekânın çok fazla müdahaleye maruz kalmadığını belirten yazar, iç mekândaki esaslı değişimin II. Bayezid Devri’nde (1481-1512) gerçekleştiğini, son restorasyon çalışmalarıyla da söz konusu dönem (XV. yüzyıl) tezyinatının yeniden ortaya çıkarıldığını açıklamaktadır. Bütün bu bilgiler, yazar tarafından belgelerle de kanıtlanmıştır (s.10).

Kalemişi Tezyinat bölümünde, türbenin iç mekânında yer alan yapı elemanı yüzeylerindeki kalemişi tezyinat anlayışı ve beslendiği kaynaklar net bir şekilde belirtilmiştir. Mevlana'nın medfun bulunduğu türbenin dört köşesinde yer alan filayaklarının yüzeyleri, güney duvar yüzeyi, yıldız tonozlu kubbenin yüzeyleri, kubbe kaidesi, taşıyıcı kemerler, ahşap gergi gibi yapının her bir unsurunun kalemişi tezyinat ile müzeyyen olduğu vurgulanır. Yazar, söz konusu alanlardaki tezyinatın

1. Baysal., A, F. (2020). Kubbe-i Hadrâ kalemişi tezyînâtı ve onarımı. Palet Yayınları.

2. Yazara ait diğer kitaplar: Yazı ve Tezyinâtıyla Edirne Eski Câmi (2014), Türk Tezyinât Sanatında Kalemişleri (2017), Akseki Yeğen Mehmet Paşa Kütüphanesi Tezhipli Kitaplar Albümü (2017).

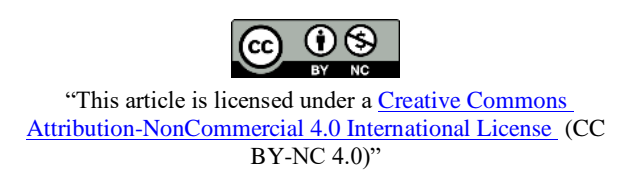
BY-NC 4.0)" 
Bursa üslûbu özelliklerini yansıttığını ve bu üslûbun oluşmasında Selçuklu sonrası Osmanlıların devlet kurma aşamasında olmasının etkili olduğunu söyler. Ayrıca bu dönemde tezyînat alanında ortaya çıkan üslûplar da detaylı bir şekilde açıklanır (s. 13).

Restorasyon Çalışmaları bölümü altındaki Hazırlık başlı̆̆ında, restorasyon çalışmasına başlamak için gereken hazırlık aşaması konu edilmiştir. Bu kısımda en başta restorasyon çalışmasının Konya Valiliği İl Kültür ve Turizm Müdürlüğü’nün koordinesi ile yapıldığına dikkat çekilerek yapının projeleri ve kalemişi tezyînatı için geniş ölçekte raporların hazırlatıldığı bilgilerine yer verilmiştir. Restorasyonun finansal desteği; Konya Ticaret Odası, Konya Sanayi Odası ve Konya Ticaret Borsası tarafından sağlanmıştır. Çalışmaların sağlıklı şekilde yürütülebilmesi için altı kişilik bilim kurulu (Prof. Dr. Serpil Bağc1, Prof. Dr. Mustafa Küçükaşçı, Prof. Dr. Ahmet Çaycı, Doç. Dr. Ali Fuat Baysal, Dr. Yaşar Erdemir, Mimar Hilmi Şenalp) oluşturulmuş, restorasyonun M. Semih İrteş ve ekibi tarafından yapılmasına karar verildiği ifade edilmiştir. 2018 yılının Mayıs ayında başlayan restorasyon çalışmalarının, altı kişilik ekibin günlük 12 saat süren çalışmasıyla 21 Mart 2019 tarihinde hızlı bir şekilde tamamlandığ vurgulanmaktadır (s. 19).

Kapsam bölümünde, restorasyon yapılan kısmın alanı belirtilmiş, restorasyona başlamadan önceki hazırlık ve tespit aşamaları ele alınmıştır. Bu bölümde öncelikle Kubbe-i Hadrâ'nın, onarım yapılacağı iç yüzeyinin detaylı fotoğrafının çekildiği ve arşivlendiği belirtilmiştir. Bununla birlikte kubbe ve duvar yüzeylerinin genel taraması yapılarak onarım ihtiyaçları ayrıntılı tespit edilmiş ve iskele kurulumunun ardından onarıma başlanmıştır. Yazar, onarım ihtiyacı tespit aşamasında, kubbe ve duvar yüzeyindeki sıvalarda bozulmaların meydana geldiğini, geçmişte yapılan onarımlar ve lokal müdahalelerle tezyînatın bozulduğunu ifade eder. Ayrıca restorasyonun raspa çalışmalarında yazı zeminlerinde hatâi ve rûmi motifli helezonların, filayaklarının üst kısımlarında geçmişte üzerleri boya ve yazı ile kapatılmış resimlerin bulunduğuna da dikkat çeker (s. 23).

Kitabın Uygulamalar isimli bölümünde yazar, restorasyon çalışmalarında iki aşamalı bir sürecin söz konusu olduğunu belirtir ve bu aşamaları açıklar. Birincisi uzun zamandır dokunulmayan veya ulaşılmayan kubbe ve duvar yüzeylerindeki kabaran ve patlayan sıvaların onarılması, ikinci aşama ise kubbe ve duvar yüzeylerindeki desenlerin aslına uygun olarak onarılmasıdır. Bu iki aşamalı süreç bu bölümde detaylı bir şekilde açıklanmıştır. Yazarın ifade ettiği bu iki aşamalı restorasyon sürecindeki en önemli özellik; boya sökücü kimyasallarla çıkartılan nakışların, orijinal renklerine bağlı kalınarak ufak dokunuşlarla yeniden hayat bulmasıdır. XV. yüzyıl kalemişlerine ulaşılabilmek amacıyla zemin araştırmasının detaylı bir şekilde yapıldığı ve bu araştırma sayesinde tezyînata dair önemli bilgilerin tespitleri de yapılan açıklamalar arasındadır (s. 25).

Kubbe, Kemerler, Güney Duvar Yüzeyi ve Kubbe Filayaklartndaki Tezyînât isimli bölümlerde, bahsi geçen bölümlerin önemli tezyîni unsurları ve detaylı restorasyon aşamaları anlatılmaktadır. Kubbe Filayaklarındaki Tezyînât bölümü içerisinde Güneydoğu Filayă̆ı, Güneybatı Filayağı, Kuzey Cephe, Kuzeydoğu Filayağı ve Kuzeybatı Filayağı alt başlıkları yer almaktadır. Bu başlıkların içerisinde yazar, özellikle güneydoğu filayağı yüzeyinin desen özünü tamamen kaybetmesinden dolayı restorasyonun en zorlu kısmı olduğunu belirtmiştir. Bu yüzeyde ciddi anlamda deforme olmuş desen, mevcut izlerden ve örneklerden faydalanılarak aslına uygun olarak çizilmiş ve uygulaması yapılmıştır (s. 59).

Kubbe-i Hadrâ Kalemişi Tezyînâtını Oluşturan Unsurlar isimli bölümde Nakışlar, Yazılar ve restorasyon sonrası ortaya çıkan Resimler alt başlıkları ele alınarak incelenmiştir. Nakışlar başlığında Kubbe-i Hadrâ'nın tezyînatında kullanılan motif gruplarına değinilmiştir. Tasarımların ana motiflerini hatâi motifler, rûmi motifler, geçmeler, dügümler, bulutlar ve münhani motiflerin yanı sıra şerit gibi devrin farklı uygulamalarının da görüldüğ̈̈ ifade edilmektedir (s. 77). Yazılar başlığı altında, duvar yüzeylerinde dönemin yoğun ve karmaşı olan tasarımlarında motiflerin arasına ilave edilen yazıların 
(ayet-i kerime, hadis-i şerif, esmâ-i hüsna ve kelam-1 kibardan sözler) müzeyyen alanın hemen her bölgesine dağıtıldığı belirtilir. Bu yazıların çoğunlukla celî sülüs ve kûfî yazılardan oluştuğunu belirten yazar; özellikle güney duvar yüzeyindeki "Besmele" ve "Kitabe" başta olmak üzere sütun başlarında büyük levhalar ve kubbe kasnağındaki yazı kuşağının, devrin hat sanatı açısından en güzel örneklerini teşkil ettiğini vurgulamaktadır. Ayrıca yazar, yapının yazılarını XV. yüzyıl Bursa üslûbu olarak nitelendirir ve bunu destekleyen örnek yazı üslûplarını da detaylı olarak açıklar (s.81). Resimler başlığında ise Kubbe-i Hadrâ'yı taşıyan dört filayă̆ın üst tarafına yapılan zemin araştırmaları sonucunda ortaya çıkarılan altı adet minyatür tarzı resim hakkında bilgi verilir. XVIII. yüzyıl üslûbunu yansıtan yazı ve desenler ile kapatılmış resimlerin temizlikleri titizlikle yapılmış, ardından eksiklikleri tamamlanarak bir bütün hâline getirildiği detaylı açıklanmıştır. Filayakları üzerine uygulanmış iki tanesi güneyde, dört tanesi kuzeyde olan resimlerin içeriğindeki tabiat motifleri ve mimari yap1 tasvirleri hakkında detaylı bilgiler verilmiştir. Ayrıca resimler ve tasvirlerin sembolik anlamları da detaylı olarak anlatılmıştır (s. 85).

Sonuç bölümünde kitapta ele alınan bölümler özetlenmiş ve genel değerlendirmeler yapılmıştır. Bu bölümde 2018 yılı Mayıs ayından beri titizlikle sürdürülen restorasyon çalışmaları sonucunda, 500 yıl kadar öncesinin özgün tasarımları ve bu tasarımlarda yer alan desen, yazı ve motiflerin ortaya çıkartılmasının öneminin büyüklüğü vurgulanır.

Restorasyon öncesi ve sonrası ortaya çıkan desen ve yazıların yanı sıra restorasyon uygulama aşamaları çok sayıda fotoğraflar eşliğinde anlatılmıştır. Özellikle restorasyon öncesi ve restorasyon sonrası fotoğraflar yan yana gösterilerek titizlikle yapılan onarım karşılaştırmalı olarak gösterilir. Sonuç olarak Mevlâna ve oğlu Sultan Veled'in medfun bulunduğu Kubbe-i Hadrâ'nın, 2018 yılında başlayan ve yaklaşık bir yıl süren kalemişi onarımı üzerinde değerlendirmede bulunan bu yayın, yapının kalemişi ve restorasyon özelliklerinin detaylı anlatıldığı önemli bir eser olması dolayısıyla söz konusu alandaki önemli bir boşluğu dolduracak niteliktedir.

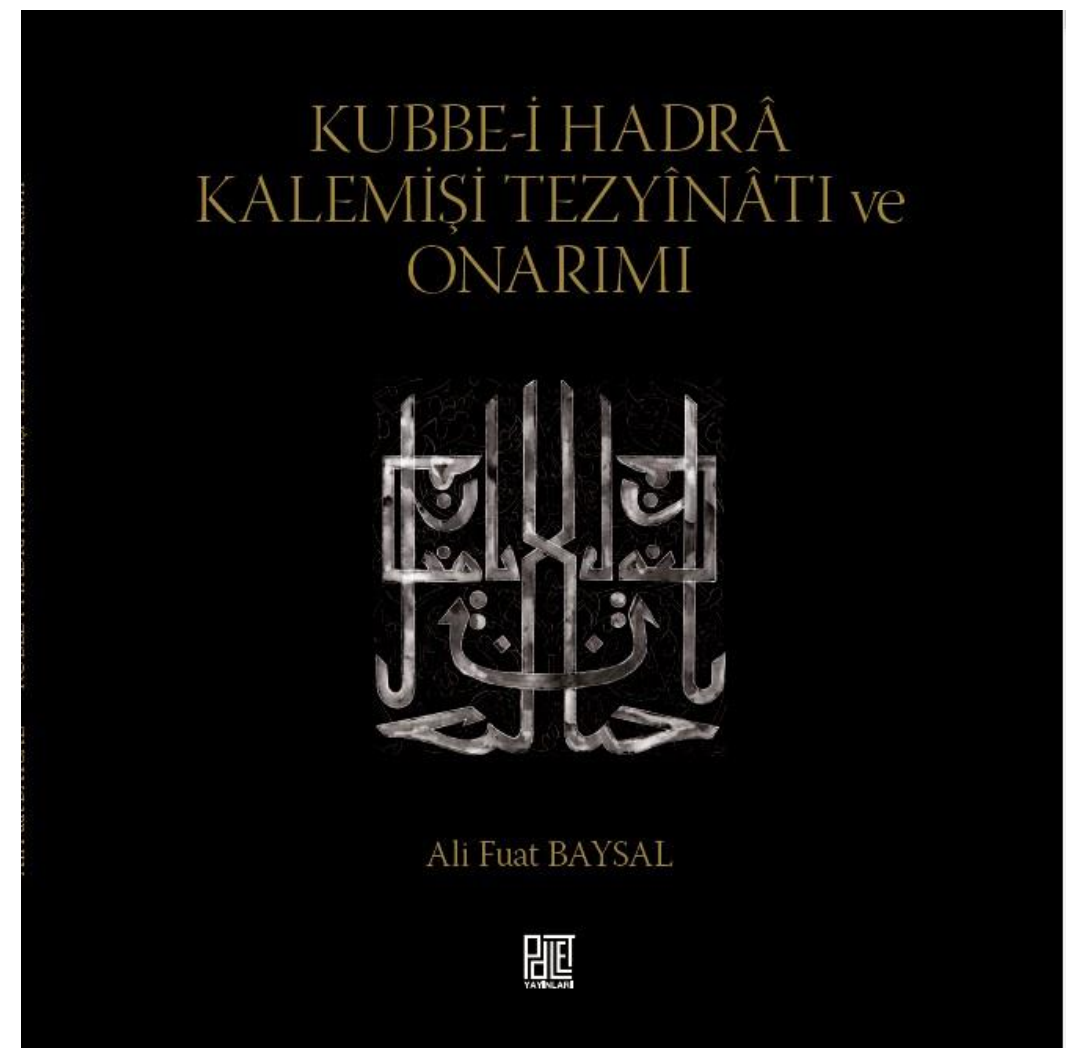

